\title{
KARAKTERISTIK SPONGE CAKE DENGAN PERLAKUAN PENAMBAHAN PASTA BIT (Beta Vulgaris L.)
}

\author{
Fatika Ambarwati ${ }^{*}$, Sri Mulyani ${ }^{2}$, Bhakti Etza Setiani ${ }^{3}$ \\ Teknologi Pangan, UniversitasDiponegoro Semarang, ully tht@yahoo.com \\ Teknologi Pangan, UniversitasDiponegoro Semarang.
}

\section{INFO ARTIKEL}

\section{RiwayatArtikel:}

Diterima: 05-01-20

Disetujui: 29-02-20

\section{Kata Kunci:}

Bit Merah

Pasta Bit

Aktifitas Antioksidan

\section{A. LATAR BELAKANG}

Cake merupakan olahan produk yang memiliki karakteristik yang khas yakni rasa manis. Cake yakni adonan yang berbahan dasar tepung terigu, gula, telur dan lemak serta dalam proses pengolahannya menggunakan pemanggangan [1]. Cake memiliki banyak jenis salah satunya adalah sponge cake. Sponge cake merupakan jenis cake dengan adonan kental serta memiliki tekstur yang agak kasar, kurang lentur, cenderung beremah apabila dipotong serta porinya relatif besar menyerupai busa sehingga sponge cake sering disebut juga dengan foam cake [2]. Kualitas mutu cake yang baik umumnya memiliki beberapa ciri yakni volume yang dihasilkan besar, crumb berpori kecil atau seragam, crust berwarna tidak terlalu coklat, dan memiliki bau khas cake. Hal ini bergantung pada bahan yang digunakan serta metode pembuatan yang benar terutama pada metode whisking [2]. Bit merah (Beta vulgaris L.) merupakan varietas bit yang memiliki warna merah dimana memiliki karakteristik daging 
buah berwarna merah, rasa sedikit manis, aroma khas tanah serta tekstur daging buah yang lunak [3]. Bit merah mengandung senyawa red betasianin dan yellow betaxanthin. Kandungan antioksidan pada bit merah yakni $1,98 \mathrm{mmol} / 100$ gram serta bit merah mengandung pigmen larut air yakni betalain 5-O-BetaGlukosa serta merupakan sumber warna yang potensial [4]. Bahan pangan yang memiliki kandungan betasianin memiliki efek antiradikal dan aktivitas antioksidan yang tinggi [5].

Pasta memiliki tekstur yang sangat halus sehingga dapat dengan mudah ditambahkan dalam suatu produk olahan pangan misalnya selai, cake, dodol serta produk olahan lainnya [6]. Dimana pada penelitian ini diharapkan penambahan pasta bit merah (Beta vulgaris L.) dapat meningkatkan kualitas mutu sponge cake. Tujuan penelitian ini adalah untuk mengetahui pengaruh penambahan pasta bit (Betavulgaris L.) terhadap karakteristik kimia yang meliputi aktifitas antioksidan, karakteristik fisik yang meliputi daya kembang, morfologi crumb, dan warna serta karakteristik sensori yang meliputi uji hedonik dan uji skoring.

\section{B. METODE PENELITIAN}

\section{Metode}

Rancangan percobaan yang digunakan pada penelitian ini menggunakan Rancangan Acak Lengkap (RAL) yang menerapkan 6 perlakuan dengan 4 kali ulangan. Perlakuan yang diberikan adalah

To : Tepung terigu $100 \%(\mathrm{~b} / \mathrm{b})$ : Pasta bit o\% (tanpa penambahan pasta bit) (kontrol)

T1 : Tepung terigu $100 \%(b / b)$ : Pasta bit 10\% (b/b)

T2 : Tepung terigu $100 \%(\mathrm{~b} / \mathrm{b})$ : Pasta bit $20 \%(\mathrm{~b} / \mathrm{b})$

$\mathrm{T}_{3}$ : Tepung terigu $100 \%(\mathrm{~b} / \mathrm{b})$ : Pasta bit $30 \%(\mathrm{~b} / \mathrm{b})$

$\mathrm{T} 4$ : Tepung terigu $100 \%(\mathrm{~b} / \mathrm{b})$ : Pasta bit $40 \%(\mathrm{~b} / \mathrm{b})$

$\mathrm{T}_{5}$ : Tepung terigu $100 \%(\mathrm{~b} / \mathrm{b})$ : Pasta bit $50 \%(\mathrm{~b} / \mathrm{b})$

Data hasil pengujian aktivitas antioksidan dijelaskan secara deskriptif. Analisa data warna, tekstur dan daya kembang sponge cake diuji secara statistik menggunakan ANOVA (Analysis of varience) pada taraf signifikasi $(\mathrm{P}<0,05)$ dan apabila terdapat pengaruh yang nyata maka dilakukan uji lanjutan menggunakan uji DMRT (Duncan Multiple Range Test). Parameter uji hedonik dianalisis menggunakan non parametrik Kruskal-Wallis dengan taraf signifikasi $(\mathrm{P}<0,05)$ apabila terdapat pengaruh yang nyata maka dilanjutkan dengan uji Mann-Whiteney. Analisis data dihitung dengan program SPSS 2.3 for Windows.

\section{Bahan Dan Alat Penelitian}

\section{a. Bahan}

Bahan yang digunakan pada penelitian ini adalah tepung terigu, telur, tepung maizena, pasta bit merah, gula pasir, cake emulsifier (SP), margarin dan baking powder.

\section{b. Alat}

Alat yang digunakan pada penelitian ini adalah penggaris, piring, nampan, loyang, mixer, oven, blender, panci, spatula, timbangan digital, gelas ukur, thermometer, baskom kecil, pisau dan sendok.

\section{Pelaksanaan Penelitian}

Penelitian ini dilakukan dalam dua tahap yakni pembuatan pasta dari umbi bit (Beta vulgaris L.) dan pembuatan sponge cake yang ditambahkan dengan pasta bit.

\section{Pembuatan Pasta Bit (Beta vulgaris L.)}

Pembuatan pasta bit merah yakni bit dikupas kulitnya dan dicuci hingga bersih kemudian dipotong dadu kecil-kecil. Potongan bit merah kemudian direbus selama kurang lebih 15 menit untuk mengurangi kadar air serta aroma tanah (langu) dari buah bit. Potongan bit merah yang telah direbus kemudian didiamkan hingga dingin, setelah itu dihaluskan dengan menggunakan blender selama kurang lebih 10 menit agar pasta bit benar-benar halus [6].

\section{Pembuatan Sponge cake Bit}

Pembuatan sponge cake dapat dilakukan dengan cara telur, gula dan SP (emulsifier) dikocok dengan menggunakan mixer dengan menggunakan kecepatan sedang (medium speed) selama 5 menit hingga tercampur rata. Tepung terigu, tepung maizena dan pasta bit ditambahkan secara perlahan kemudian diaduk menggunakan mixer dengan kecepatan tinggi (high speed) selama 7 menit. Pasta bit ditambahkan sesuai dengan perlakuan. Pengocokan adonan dilakukan hingga adonan berwarna pucat dan kental kemudian kecepatan mixer diturunkan menjadi kecepatan rendah (low speed). Margarin dilelehkan kemudian dicampurkan kedalam adonan. Dalam pencampuran margarin hanya perlu menggunakan spatula saja tidak perlu menggunakan mixer. Namun, pastikkan margarin benar-benar tercampur secara sempurna. Adonan sponge cake dituang kedalam loyang berukuran 18 x $20 \mathrm{~cm}$ yang dibagian bawah telah dilapisi kertas baking dan diolesi margarin. Adonan yang telah siap kemudian dimasukkan kedalam oven. Pemanggangan cake dilakukan selama \pm 30 menit dengan menggunakan suhu $180^{\circ} \mathrm{C}$ (Ananto, 2014). Sponge cake yang telah matang kemudian ditunggu \pm 1 menit dan dilepaskkan dari loyang dengan cara dibalik.

\section{Parameter Pengamatan}

Parameter pada penelitian ini meliputi karakteristik kimia yakni aktivitas antioksidan, karakteristik fisik yakni daya kembang, morfologi 
crumb dan warna serta karakteristik sensori yakni uji hedonik dan uji skoring.

\section{Aktifitas Antioksidan}

Uji antioksidan dengan menggunakan metode DPPH [7]. Pengujian sampel dilakukan dengan cara sampel ditimbang $1 \mathrm{~g}$ ditambah etanol $10 \mathrm{ml}$ kemudian didiamkan selama 3 hari didalam wadah tertutup pada suhu ruang hingga terbentuk supernatan. Supernatan disaring menggunakan kertas saring dan filtrate yang diperoleh sebanyak 2 $\mathrm{ml}$ dan direaksikan dengan $2 \mathrm{ml}$ larutan DPPH (2,2 - diphenyl - 1 - picrylhydrazyl). Aktifitas antioksidan terukur dihitung dengan menggunakan rumus :

Aktifitas antioksidan (\%) $=[$ (absorbansi control absorbansi sampel) / absorbansi control]

\section{Daya Kembang}

Daya kembang merupakan penambahan volume cake selama pemanggangan. Pengukuran daya kembang dilakukan dengan cara mengukur tinggi adonan cake sebelum dioven dan dicatat sebagai $\mathrm{T}_{1}$ kemudian mengukur tinggi adonan cake setelah dioven dan dicatat sebagai $\mathrm{T}_{2}$. Tinggi adonan yang telah didapat kemudian dihitung menggunakan rumus berikut [8].

Daya Kembang (\%) $=\frac{\mathrm{T} 2-\mathrm{T} 1}{\mathrm{~T} 1} X 100$

Keterangan :

$\mathrm{T}_{2}=$ Tinggi adonan cake setelah di oven .

$\mathrm{T}_{1}=$ Tinggi adonan cake sebelum di oven .

\section{Analisis Morfologi Crumb}

Morfologi crumb merupakan bagian pada cake yang terdapat didalam atau antar sel. Morfologi crumb terbentuk dari busa yang dihasilkan pada saat proses pengocokan adonan (Sutedja et al., 2015). Analisis morfologi crumb dapat dilakukan dengan carasponge cake diiris dengan ketebalan \pm 2 $\mathrm{cm}$ kemudian diletakkan diatas alas dan dilakukan pemotretan terhadap struktur crumb cake. Gambar yang dihasilkan kemudian dibandingkan antara sponge cake yang satu dengan yang lainnya [9].

\section{Analisis Warna}

Uji warna pada penelitian ini yakni dilakukan dengan mengetahui warna yang terdapat pada sampel yang diuji. Berdasarkan warna $L^{*} a^{*} b$ menggunakan digital color meter. Hasil pengukuran ditentukan dalam bentuk notasi Hunter yang meliputi $\mathrm{L}=$ kecerahan (skor $\mathrm{O}=$ hitam gelap sampai $100=$ putih terang); a, dengan (-a) menyatakan warna hijau dan (+a) menyatakan warna merah; dan $b$, dengan (-b) menyatakan warna biru dan $(+b)$ menyatakan warna kuning [10].

\section{Uji Organoleptik}

Uji organoleptik yang digunakan pada penelitian ini yakni uji sifat organoleptik dan uji hedonik dengan menggunakan metode skoring. Uji sifat organoleptik merupakan cara pengujian atau penilaian menggunakan alat indera dengan menggunakan uji hedonik atau kesukaan yang menyatakan panelis suka atau tidak terhadap sponge cake. Uji hedonik adalah pengujian yang dilakukan dengan menggunakan skala hedonik atau tingkat kesukaan. Pada penelitian ini skala yang digunakan untuk memudahkan panelis maka menggunakan lima tingkatan. Pengujian hedonik menggunakan angka 5 skala numeric [11].

\section{HASIL DAN PEMBAHASAN}

\section{Aktifitas antioksidan}

Hasil pengujian aktifitas antioksidan pada sponge cake dengan penambahan pasta bit yang berbeda dapat dilihat pada ilustrasi 1 .

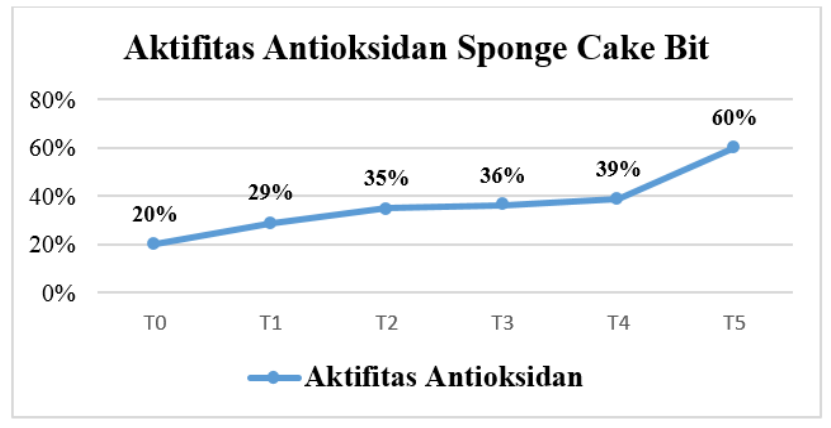

Gambar 1. Aktifitas Antioksidan Sponge Cake Bit

Keterangan :

$\mathrm{T}_{0}-\mathrm{T}_{5}=$ Penambahan konsentrasi pasta bit $\mathrm{o} \%$; 10\%; 20\%; 30\%; 40\% dan 50\%

Berdasarkan Ilustrasi 1. Dapat diketahui bahwa semakin tinggi penambahan bit pada sponge cake semakin tinggi pula aktifitas antioksidan yang terkandung didalamnya. Hal ini disebabkan karena semakin banyaknya kandungan antioksidan yang ada didalamnya. Dimana ditandai dengan penuruan intensitas warna ungu pada pengujian dengan metode DPPH. Hal ini sesuai dengan pendapat [12] bahwa metode DPPH merupakan metode pengujian aktifitas antioksidan karena mudah, cepat serta sensitif. Keberadaan senyawa antioksidan pada pengujian DPPH dapat mengubah larutan DPPH yang semula ungu menjadi berwarna kekuningan. Penambahan pasta bit merah pada produk sponge cake mampu meningkatkan aktifitas antioksidan. Hal ini dikarenakan bit merah memiliki kandungan senyawa flavonoid,betasianin, asam askorbat, serta karotenoid.Hal ini sesuai dengan pendapat [13] yang menyatakan bahwa buah bit merupakan salah satu tanaman yang mengandung betasianin dimana senyawa tersebut mampu mengurangi kerusakan sel akibat senyawa oksidatif. 


\section{Daya Kembang}

Hasil pengujian daya kembang sponge cake dengan penambahan pasta bit dapat dilihat pada Tabel 1.

Tabel 1.

Hasil Analisis Daya Kembang Sponge cake Bit

\begin{tabular}{cc}
\hline Perlakuan & Daya Kembang \\
\hline $\mathrm{T}_{\mathrm{o}}$ & $75,50 \pm 7,59$ \\
$\mathrm{~T}_{1}$ & $75,25 \pm 6,39$ \\
$\mathrm{~T}_{2}$ & $72,00 \pm 15,34$ \\
$\mathrm{~T}_{3}$ & $73,50 \pm 4,50$ \\
$\mathrm{~T}_{4}$ & $70,00 \pm 8,12$ \\
$\mathrm{~T}_{5}$ & $74,75 \pm 3,50$ \\
\hline
\end{tabular}

Keterangan : Data ditampilkan sebagai nilai rerata dari 4 ulangan $\pm \mathrm{SD}$

$\mathrm{T}_{0}-\mathrm{T}_{5}=$ Penambahan konsentrasi pasta bit 0\%; 10\%; 20\%; 30\%; 40\% dan 50\%

Berdasarkan uji Anova, penambahan pasta bit pada sponge cake tidak memiliki pengaruh yang nyata pada daya kembang sponge cake. Dimana penambahan pasta bit pada pembuatan sponge cake tidak mempengaruhi daya kembang sponge cake secara nyata. Hal ini dikarenakan kadar air pada pasta bit relatif berkurang dibandingkan bit segar sehingga tidak mempengaruhi kemampuan tepung terigu dalam mengikat bahan-bahan lain. Hal ini sesuai dengan pendapat [14] yang menyatakan bahwa daya kembang cake dapat dipengaruhi oleh beberapa faktor salah satunya yakni kadar air. Protein gluten pada tepung terigu memiliki daya serap yang tinggi dikarenakan gluten membutuhkan air lebih banyak untuk dapat menyimpan gas sebanyak-banyaknya. Hal ini sesuai dengan pendapat [15] yang menyatakan bahwa faktor-faktor yang dapat mempengaruhi daya kembang cake yakni berasal dari bahan-bahan yang digunakan serta teknik mixing yang dilakukan saat proses pembuatan. Dimana adonan yang mengembang maksimal menyebabkan volume yang dihasilkan semakin besar pula. Bahan cake yangdapat mempengaruhi pengembangan menjadi baik yakni telur dan emulsifier. Penambahan pasta bit memiliki karakteristik yakni kadar air yang tinggi. Namun, pada penelitian ini kadar air pasta bit dapat menyatu dengan bahan-bahan yang lain. Hal ini disebabkan adanya penggunaan tepung terigu serta tepung maizena pada proses pembuatannya sehingga daya serapnya tinggi.

\section{Morfologi Crumb}

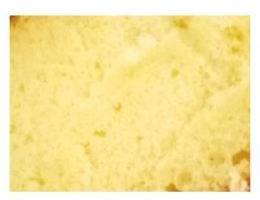

$\mathrm{T}_{0}$

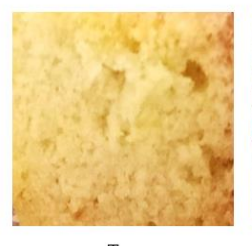

$\mathrm{T}_{3}$

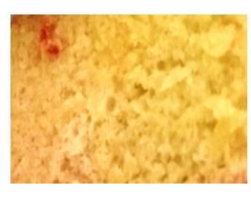

$\mathrm{T}_{1}$

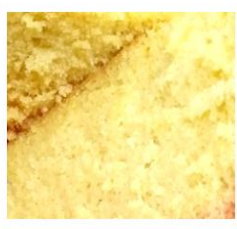

$\mathrm{T}_{4}$

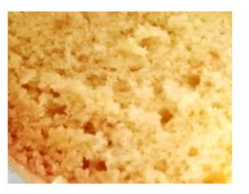

$\mathrm{T}_{2}$

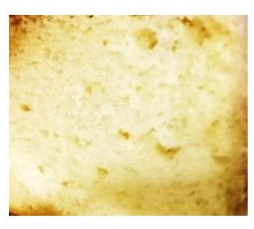

$\mathrm{T}_{5}$
Gambar 2. Morfologi Crumb

Morfologi crumb yang dihasilkan pada perlakuan $\mathrm{T}_{0}, \mathrm{~T}_{4}$, dan $\mathrm{T}_{5}$ memiliki poricrumb yang rapat dan kecil sedangkan pada perlakuan $T_{1}, T_{2}$ $\operatorname{danT}_{3}$ memiliki beberapa pori crumb yang tidak seragam. Hal ini disebabkan karena adanya fenomena tidak terperangkapnya gelembung gas secara sempurna sehingga mengakibatkan cake tidak memiliki pori kecil dan seragam [16]. Hal ini sesuai dengan pendapat [17] yang menyatakan bahwa fenomena pembentukkan crumb pada cake terjadi akibat adanya proses mixing. Pori-pori (rongga antar sel) dibentuk oleh busa yang dihasilkan oleh telur, gula dan cake emulsifier (SP). Melalui proses mixing terjadinya pembentukan lapisan monomolekuler yang siap menangkap udara. Pada proses pemanasan $\mathrm{O}_{2}$ akan memuai bersama dengan pati sehingga membentuk pori.

\section{Warna}

Tabel 2.

Hasil Penelitian Warna Sponge cake Bit

\begin{tabular}{cccc}
$\begin{array}{c}\text { Perlakua } \\
\mathbf{n}\end{array}$ & $\begin{array}{c}\text { Warna } \\
\left(\mathbf{L}^{*}\right)\end{array}$ & Warna $\left(\mathbf{a}^{*}\right)$ & $\begin{array}{c}\text { Warna } \\
\left(\mathbf{b}^{*}\right)\end{array}$ \\
\hline $\mathrm{T}_{0}$ & $75,37 \pm 3,56^{\mathrm{b}}$ & $22,40 \pm 39,72^{\mathrm{a}}$ & $30,08 \pm 1,14^{\mathrm{a}}$ \\
$\mathrm{T}_{1}$ & $72,51 \pm 1,18^{\mathrm{b}}$ & $00,76 \pm 2,17^{\mathrm{ab}}$ & $32,19 \pm 1,80^{\mathrm{a}}$ \\
$\mathrm{T}_{2}$ & $73,16 \pm 4,57^{\mathrm{b}}$ & $00,89 \pm 0,93^{\mathrm{ab}}$ & $31,25 \pm 2,87^{\mathrm{a}}$ \\
$\mathrm{T}_{3}$ & $64,91 \pm 3,40^{\mathrm{a}}$ & $4,17 \pm 2,11^{\mathrm{ab}}$ & $31,34 \pm 1,99^{\mathrm{a}}$ \\
$\mathrm{T}_{4}$ & $65,24 \pm 3,80^{\mathrm{a}}$ & $3,81 \pm 2,56^{\mathrm{ab}}$ & $32,48 \pm 1,44^{\mathrm{a}}$ \\
$\mathrm{T}_{5}$ & $64,84 \pm 4,66^{\mathrm{a}}$ & $5,79 \pm 2,44^{\mathrm{b}}$ & $33,12 \pm 4,08^{\mathrm{a}}$ \\
\hline
\end{tabular}

Keterangan :

Data ditampilkan sebagai nilai rerata dari 4 ulangan \pm SD

$\mathrm{T}_{0}-\mathrm{T}_{5}=$ Penambahan konsentrasi pasta bit $0 \% ; 10 \% ; 20 \%$; 30\%; 40\% dan 50\%

Dimana semakin tinggi penambahan konsentrasi pasta bit maka warna $\mathrm{L}^{*}$ (light) pada sponge cake semakin menurun. Hal ini disebabkan karena adanya penambahan pasta bit ke dalam sponge cake sehingga warna yang dihasilkan lebih merah kecoklatan. Nilai $\mathrm{L}^{*}$ yang paling tinggi yakni perlakuan $\mathrm{T}_{\mathrm{o}}$ yakni 75,37 sedangkan yang paling rendah yakni $\mathrm{T}_{5}$ sebesar 64,84 . Nilai $\mathrm{a}^{*}$ yang paling 
tinggi yakni perlakuan $\mathrm{T}_{5}$ yakni 5,79 sedangkan yang paling rendah yakni $\mathrm{T}_{0}$ sebesar -22,4. Nilai $\mathrm{b}^{*}$ yang paling tinggi yakni perlakuan $\mathrm{T}_{5}$ yakni 33,12 sedangkan yang paling rendah yakni $\mathrm{T}_{0}$ sebesar 30,08. Hal ini sesuai dengan pendapat 18] yang menyatakan bahwa nilai kecerahan $\left(\mathrm{L}^{*}\right)$ dan kekuningan $\left(\mathrm{b}^{*}\right)$ padasponge cake diperoleh dari adanya penambahan telur sehingga menyebabkan nilai kecerahan $\left(\mathrm{L}^{*}\right)$ serta kekuningan $\left(\mathrm{b}^{*}\right)$ muncul yang ditandai dengan pigmen warna kekuningan. Namun perbedaan intensitas kecerahan $\left(\mathrm{L}^{*}\right)$ dan kekuningan $\left(b^{*}\right)$ berhubungan dengan adanya penambahan konsentrasi pasta bit pada setiap perlakuan. Dimana semakin tinggi penambahan konsentrasi pasta bit maka nilai kecerahan $\left(L^{*}\right)$ menurun. Hal ini sesuai dengan pendapat [19]yang menyatakan b ahwa penambahan pasta bit kedalam sponge cake menyebabkan nilai kecerahannya turun karena disebabkan adanya pigmen betasianin pada bit yang menyebabkan warna sponge cake menjadi sedikit merah gelap sehingga nilai kemerahan $\left(\mathrm{a}^{*}\right)$ yang paling tinggi yakni perlakuan dengan penambahan bit paling banyak yakni $\mathrm{T}_{5}$.

\section{Mutu Organoleptik}

Tabel 3.

Hasil Pengujian Mutu Organoleptik Pada Sponge cake Bit

\begin{tabular}{ccccc}
\hline $\begin{array}{c}\text { Perla } \\
\text { kuaan }\end{array}$ & Rasa & Aroma & Tekstur & Overall \\
\hline $\mathrm{T}_{0}$ & $4,04 \pm 0,97^{\mathrm{b}}$ & $4,24 \pm 1,16^{\mathrm{b}}$ & $4,40 \pm 0,70^{\mathrm{b}}$ & $4,24 \pm 0,97^{\mathrm{c}}$ \\
$\mathrm{T}_{1}$ & $3,40 \pm 0,81$ & $3,48 \pm 1,08$ & $3,16 \pm 1,06$ & $3,24 \pm 0,97$ \\
$\mathrm{~T}_{2}$ & $3,48 \pm 0,82^{\mathrm{a}}$ & $3,44 \pm 0,91^{\mathrm{a}}$ & $3,36 \pm 0,81^{\mathrm{a}}$ & $3,64 \pm 0,70^{\mathrm{ab}}$ \\
$\mathrm{T}_{3}$ & $3,52 \pm 0,71^{\mathrm{a}}$ & $3,84 \pm 0,85^{\mathrm{ab}}$ & $3,16 \pm 0,85^{\mathrm{a}}$ & $3,44 \pm 0,68^{\mathrm{a}}$ \\
$\mathrm{T}_{4}$ & $3,76 \pm 0,59^{\mathrm{ab}}$ & $3,96 \pm 0,53^{\mathrm{ab}}$ & $3,36 \pm 0,81^{\mathrm{a}}$ & $3,36 \pm 0,70^{\mathrm{a}}$ \\
$\mathrm{T}_{5}$ & $3,72 \pm 0,61^{\mathrm{ab}}$ & $4,16 \pm 0,68^{\mathrm{b}}$ & $3,40 \pm 0,86^{\mathrm{a}}$ & $4,00 \pm 0,57 \mathrm{bc}$
\end{tabular}

Keterangan :

Rasa = 1: sangat tidak manis ; 2: manis; 3: agak manis; 4: manis dan 5: sangat manis

Aroma $=1$ : sangat langu ; 2: langu; 3: agak langu; 4: tidak langu dan 5: sangat tidak langu

Tekstur $=1$ : sangat tidak lembut ; 2:tidak lembut; 3: agak lembut; 4: lembut dan 5: sangat lembut

Overall = 1: sangat tidak suka ; 2: tidak suka; 3: agak suka; 4: suka dan 5: sangat suka

Data ditampilkan sebagai nilai rerata dari 4 ulangan \pm SD

$\mathrm{T}_{0}-\mathrm{T}_{5}=$ Penambahan konsentrasi pasta bit $0 \% ; 10 \% ; 20 \%$; 30\%; $40 \%$ dan $50 \%$

*Superscript yang berbeda menunjukkan perbedaan nyata $(\mathrm{P}<0,05)$

\section{a. Rasa}

Penambahan pasta bit pada produk sponge cake tidak berpengaruh nyata pada rasa manis yang ditimbulkan dengan rerata tingkat rasa $(\mathrm{P}>0.05)$ berkisar antara 3,4 sampai 4,04 yang berarti bahwa tingkat rasa yakni agak manis (3). Kesukaan panelis terhadap rasamanis cenderung stabil seiring dengan penambahan pasta bit. Hal ini sesuai dengan pendapat [20] yang menyatakan bahwa umbi bit mengandung senyawa geosmin. Senyawa geosmin dihasilkan dari bakteri gram positif yakni Streptomyces dimana bakteri memiliki aroma khas tanah (earth taste) sehingga mempengaruhi rasa yang ditimbulkan pada sponge cake. Namun, rasa manis yang ditimbulkan juga dipengaruhi oleh gula alami yang terkandung dalam bit. Hal ini sesuai dengan pendapat [20] yang menyatakan bahwa bit merupakan salah satu tanaman yang umumnya digunakan sebagai pemanis pada suatu produk. Hal ini dikarenakan bit memiliki kandungan gula sukrosa yang cukup tinggi yakni sekitar 6\%. Gula sukrosa berfungsi untuk memberikan rasa manis yang khas pada suatu produk.

\section{b. Aroma}

Penambahan pasta bit pada produk sponge cake berpengaruh nyata pada aroma yang ditimbulkan $(\mathrm{P}<0.05)$. Rerata tingkat aroma pada sponge cake bit yakni 3,44 sampai 4,24 yang berarti bahwa tingkat aroma yakni agak langu (3) dan tidak langu (4). Berdasarkan analisis statistik dapat diketahui bahwa semakin bertambahnya konsentrasi pasta bit yang ditambahkan pada sponge cake memberikan pengaruh nyata dimana aroma langu yang ditimbulkan cenderung meningkat. Hal ini disebabkan karena bit memiliki aroma langu atau bau khas umbi akar (tanah). Hal ini sesuai dengan pendapat [20] yang menyatakan bahwa umbi bit mengandung senyawa geosmin. Senyawageosmin dihasilkan dari bakteri gram positif yakni Streptomyces dimana bakteri memiliki aroma khas tanah (earth taste). Hal ini menyebabkan umbi bit memiliki aroma tanah. Hal ini sesuai dengan pendapat [21] yang menyatakan bahwa umbi bit umumnya menghasilkan aroma earth taste atau yang biasa disebut dengan aroma tanah/langu. Namun, ada beberapa proses yang dapat mengurangi aroma tanah dari umbi bit yakni dengan mengukus, blanching, dan pengasaman. Pada proses pembuatan pasta bit, aroma tanah (earth taste) sedikit berkurang karena adanya perlakuan pengukusan dimana pada proses ini dapat menginaktivasi enzim katalase dan peroksidase yang menyebakan adanya aroma tanah.

\section{c. Tekstur}

Berdasarkan hasil analisis secara statistik diperoleh hasil bahwa Penambahan pasta bit pada produk sponge cake berpengaruh nyata pada tekstur yang ditimbulkan $(\mathrm{P}<0.05)$. Rerata tingkat tekstur berkisar antara 3,16 sampai 4,40 yang artinya agak lembut (3) sampai lembut (4). Penambahan pasta bit pada sponge cake menghasilkan tekstur yang kurang lembut dibandingkan dengan sponge cake yang tidak ditambahkan dengan pasta bit. Hal ini 
dikarenakan kandungan air pada pasta bit yang cukup tinggi yakni berkisar antara $\pm 60 \%$ sehingga pori-pori yang di dapat sedikit dan rapat sehingga hasilnya kurang lembut. Hal ini sesuai dengan pendapat [22] yang menyatakan bahwa tekstur sponge cake umumnya dapat dilihat dari pori-pori yang didapatkan. Dimana semakin banyak pori-pori yang dihasilkan maka semakin lembut tekstur yang dihasilkan. Hal tersebut dipengaruhi oleh protein didalam tepung terigu yang digunakan apabila protein rendah maka semakin sedikit pori-pori yang diperoleh. Dimana umbi bit mengandung protein yang sangat rendah yakni 1,6 gram. Hal ini sesuai dengan pendapat [23] yang menyatakan bahwa umbi bit merupakan bahan pangan yang memiliki kandungan protein yang rendah serta kandungan air yang tinggi hal ini menyebabkan tekstur yang diperoleh tidak lembut karena menjadi beban tambahan pada adonan.Hal ini sesuai dengan pendapat [23] yang menyatakan bahwa kandungan air yang banyak pada saat proses pemangangan akan menyebabkan penguapan yang berlebih karena tidak ada gluten yang dapat mengikat air lebih banyak sehingga cake yang dihasilkan lebih keras setelah didinginkan.

\section{d. Overall}

Berdasarkan hasil analisis secara statistik diperoleh hasil bahwa Penambahan pasta bit pada produk sponge cake berpengaruh nyata pada overall yang ditimbulkan $(\mathrm{P}<0.05)$. Rerata tingkat kesukaan panelis terhadap parameter keseluruhan produk yang dihasilkan yaitu berkisar antara 3,24 sampai 4,24. Ini berarti tingkat kesukaan panelis terhadap sponge cake bit dengan ekstrak bit berkisar antara cukup suka (3) hingga suka (4). Berdasarkan analisis statistik menunjukkan adanya pengaruh karena sponge cake yang dihasilkan mempengaruhi rasa manis, aroma dan tesktur. Hal ini sesuai dengan hasil yang diharapkan dimana penambahan pasta bit pada sponge cake tidak merubah ataupun menurunkan kualitas standar mutu pada produk. Dimana hasil yang diinginkan hanya meningkatkan komponen yang diinginkan saja. Hal ini sesuai dengan pendapat [24] yang menyatakan bahwa penambahan pasta bit pada suatu produk diharapkan dapat meningkatkan efek kesehatan serta meningkatkan sensoris pada produk. Pada penelitian ini penambahan pasta bit pada sponge cake tidak mempengaruhi kesukaan panelis secara keseluruh

\section{SIMPULAN DAN SARAN}

\section{Simpulan}

Berdasarkan penelitian yang telah dilakukan dapat disimpulkan bahwa penambahan pasta bit pada produk sponge cake dapat meningkatkan aktifitas antioksidan, warna $\left(\mathrm{L}^{*}\right)$, aroma, tekstur serta overall namun penambahan pasta bit tidak meningkatkan parameter daya kembang, morfologi crumb, warna $\left(\mathrm{a}^{*}\right)$ dan $\left(\mathrm{b}^{*}\right)$, serta mutu organoleptik rasa pada sponge cake. Perlakuan terbaik penambahan pasta bit pada produk sponge cake yakni penambahan pasta bit sebanyak 50\% (T5).

\section{Saran}

Hasil penelitian penambahan pasta bit pada sponge cake dapat digunakan sebagai acuan untuk menghasilkan mutu cake yang baik selain itu penambahan pasta bit dapat meningkatkan kandungan gizi pada sponge cake yakni antioksidan.

\section{UCAPAN TERIMA KASIH}

Penulis mengucapkan terima kasih kepada Dr. Sri Mulyani, S.Pt., M.P dan Bhakti Etza Setiani, S.Pt., M.Sc selaku Pembimbing Skripsi yang senantiasa memberikan bimbingan, nasehat, dan motivasi kepada penulis sehingga penelitian ini selesai dengan baik.

\section{DAFTAR RUJUKAN}

[1] Handayani, R. dan S. Aminah., Variasi Subtitusi Rumput Laut Terhadap Kadar Serat Mutu Organoleptik Cake Rumput Laut (Eucheuma cottonii),Jurnal Pangan dan Gizi, Vol 2, No. 3, h. 65-69, 2011.

[2] Chandra P, D. I. N. K. A., Pengaruh Substitusi Tepung Tiwul Tawar Instan Dan Metode Pengocokan Terhadap Sifat Organoleptik Sponge Cake, Jurnal Tata Boga, Vol7, No. 2, h. 188-97, 2018.

[3] Andersen, Q.M., and Markham, K.R., Flavanoid: Chemistry, Biochemistry and Aplication.CRC Press, USA. Vol 12, No. 2, h. 2-11, 2006.

[4] Nemzer, B., Zbigniew, P., Aneta S, Pawel, S., Wayne, T., and Tadeusz,M., Betalainic And Nutritional Profiles Of Pigment-Enriched Red BitRoot (Beta Vulgaris L.) Dried Extracts, Food Chemistry, Vol 127, h. 42-53, 2011.

[5] Mastuti., Yizhong, C., Harold, C., Identifikasi Pigmen Betasianin Pada Beberapa Jenis Inflorescence Celosia, Jurnal Biologi UGM, Vol 66, No. 6, h. 664-672, 2010.

[6] Hidayat, F., Farida, A., Ermaya, D., dan Sholihati, S., Kajian Penambahan Pasta Umbi Bit Merah (Beta vulgaris L) dan Tepung Kacang Hijau (Phaseolus radiatus L) dalam Pembuatan Roll Cookies, Rona Teknik Pertanian, Vol12, No. 1, h.1-11, 2019.

[7] Hasim , H., Adrianto, D., Lestari, E. D., dan Fardah, D, N., Aktivitas antioksidan ekstrak sulur buah naga putih (Hylocereus undatus) dengan metode DPPHdan rancimat. Jurnal Gizi dan Pangan.Vol 12, No. 3, h. 203-210, 2017.

[8] Fitriani, N. D dan Hersoelistyorini, W., Substitusi Tepung Kulit Singkong Terhadap Daya Kembang, Kadar Serat, Dan Organoleptic Pada Chiffon Cake,Jurnal Pangan dan Gizi, Vol 3, No. 2, h. 1-10, 2016.

[9] Ekayani, I. A. P. H., Efisiensi Penggunaan Telur dalam Pembuatan Sponge cake, Jurnal Pendidikan Teknologi dan Kejuruan, Vol 8, No. 2, h. 58-74, 2011.

[10] Hutching, JB., Food Color And Apperance Second Edition. An Aspen Publ. Inc, Gaithersburg, Maryland, 1999.

[11] Meilgaard, M., Sensory Evaluation Techniques $3^{\text {rd }}$ edition. CRC Press, Washington, D. C, 1999. 
[12] Sari, N. M. I., A. M. Huda. dan W. Prihanta., Uji Kadar Betasianin Pada Buah Bit (Beta Vulgaris L) Dengan Pelarut Etanol Dan Pengembangannya Sebagai Sumber Belajar Biologi, Jurnal Pendidikan Biologi Indonesia, Vol 2, No. 1, h. 72-77, 2016.

[13] Delgado-vargas, F., A. R. Jimenez and O. Parades-lopez., Natural Pigments : carotenoids, anthocyanins, and betalains-characteristics, biosynthesis, processing and stability,Critical Reviews in Food Science And Nutrition, Vol 40, h. 173-289, 2000.

[14] Adeleke, R.O., dan Odedeji, J.O.,"Functional Properties of Wheat and Sweet Potato Flour Blends",Pakistan. Journal of Nutrition. Vol 9, No. 6, h. 535-538, 2010.

[15] Anggraini, T., Y. K. Dewi dan K. Sayuti. Karakteristik Sponge Cake Berbahan Dasar Tepung Beras Merah, Hitam Dan Putih Dari Beberapa Daerah Di Sumatera Barat, Jurnal Litbang Industri,Vol 7, No. 2, h. 123-126, 2017.

[16] Scanlon, M. G., Henrich, A. W., and Whitaker, J. R., Factors Affecting Enzyme Activity In Food Processing. In Proteins in Food Processing, Woodhead Publishing,h. 337-365, 2018.

[17] Yunieta, M., dan Sutrisno, A., Penggunaan Pasta Ubi Kayu (manihot esculenta crantz) Sebagai Bahan Baku Pembuatan Cake, Jurnal Pangan dan Agroindustri, Vol 6, No. 2, h. 1-12, 2019.

[18] Goranova, Z., Baeva, M., Stankov, S., and Zsivanovits, G., Sensory Characteristic and Textural Changes during Storage of Sponge Cake with Functional Ingredient,Journal of Food Physics, Vol 28-29, No. 1, h. 70-79, 2015.

[19] Rahmayuni, U. Pato, V. S. Johan dan M. A. Solihin., Subtitusi Tepung Terigu Dengan Pati Sagu Dalam Proses Pembuatan Cake, Jurnal Agriculturan Science dan Techhnology, Vol 11, No. 2, h. 1-13, 2013.

[20]Lu, G., C. G. Edwards, J. K. Fellman, D. S. Mattinson and J. Navazio., Biosynthetic origin of geosmin in red beets (Beta vulgaris L), Journal Agriculture and Food Chemistry, Vol 51, h. 1026-1029, 2003.

[21] Asgar, A dan D. Musaddad.,Optimasi Cara, Suhu, Dan Lama Blansing Sebelum Pengeringan Pada Wortel. Jurnal Hortikultura, Vol 16, No. 3, h. 245-252, 2006.

[22] Bayon, M.A., Pozo, Rodriguez, A.R., Pernin, K. and Cayot, N., Aroma Influence Of Eggs On The Aroma Composition Of A Sponge Cake And On The Aroma Release In Model Studies On Flavored Sponge Cakes,Journal of. Agricultural and Food Chemistry, Vol 55, h. 1418-1426, 2017.

[23] El-Faham, S.Y., El-Rahiem, A., and Saleh, O.S., Free Gluten Cake And Tortilla From Cassava And Pre Gelatinized White Rice Flours,International Journal of Science and Research, Vol3, No. 10, h. 634-638, 2014.

[24] Handayani, R. dan S. Aminah., Variasi Subtitusi Rumput Laut Terhadap Kadar Serat Mutu Organoleptik Cake Rumput Laut (Eucheuma cottonii),Jurnal Pangan dan Gizi, Vol 2, No. 3, h. 65-69, 2011. 